\title{
PENERAPAN PRINSIP WADI'AH, MUDHARABAH, DAN MURABAHAH PADA LEMBAGA KEUANGAN SYARIAH : STUDI PADA BMT AL-HIKMAH UNGARAN TIMUR
}

\author{
Nur Hamidah \\ Universitas Islam Sultan Agung Semarang \\ Jl. Kaligawe Km. 4 Semarang. 50012 \\ nhk3496@gmail.com
}

\begin{abstract}
Abstrak
$\mathrm{T}$ ujuan dari penelitian ini adalah sebagai berikut: pertama, untuk mengetahui bagaimana penerapan prinsip wadi' ah, mudharabah, dan murabahah pada BMT ALHIKMAH. Kedua, mengetahui apakah penerapan prinsip wadi'ah, mudharabah, dan murabahah pada BMT AL-HIKMAH dilakukan sesuai dengan prinsip syariah yang berlaku. Dan Ketiga, untuk mengetahui Bagaimana penerapan prinsip wadi'ah, mudharabah, dan murabahah pada BMT AL-HIKMAH yang sesuai dengan prinsip syariah yang berlaku. Setelah diadakan penelitian lebih rinci maka diperoleh hasil bahwa BMT AL-HIKMAH sebagai lembaga keuangan syariah telah menerapkan prinsip wadi'ah, mudharabah, dan murabahah sesuai dengan prinsip hukum syariah yang berlaku.
\end{abstract}

Kata Kunci: Prinsip Wadi'ah, Prinsip Mudharabah, Prinsip Murabahah, Prinsip Syariah, Lembaga Keuangan Syariah

\begin{abstract}
$T$ he purpose of this study are as follows: first, to know how the application of the principle of wadi'ah, mudaraba, and murabaha at BMT AL-HIKMAH. Second, whether the application of the principle of wadi'ah, mudaraba, and murabaha at BMT ALHIKMAH conducted in accordance with the principles of Shariah. And thirdly, to determine the application of how the principle wadi'ah, mudaraba, and murabaha at BMT AL-HIKMAH in accordance with shariah principles. Having conducted a more detailed study of the obtained results that the BMT AL-HIKMAH as Islamic financial institutions have applied the principle wadi'ah, mudaraba, murabaha and in accordance with the principles of Shariah law.
\end{abstract}

Keywords: Wadi'ah Principle, The Principle of Mudaraba, Murabaha Principles, Principles Of Sharia, Islamic Financial Institutions.

\section{Pendahuluan}

Baitul Maal wat Tamwil atau biasa disebut BMT merupakan lembaga keuangan syariah yang menggunakan berbagai macam prinsip dalam kegiatan usahanya. Prinsip yang digunakan oleh BMT antara lain prinsip syariah, prinsip demokrasi ekonomi, dan prinsip kehati-hatian. Menurut UU No. 21 Tahun 2008 tentang prinsip syariah menerangkan bahwa prinsip syariah adalah prinsip hukum islam dalam kegiatan perbankan berdasarkan fatwa yang dikeluarkan oleh lembaga yang memiliki kewenangan dalam penetapan fatwa di bidang syariah. Selain itu, UU No. 21 Tahun 2008 juga menyatakan bahwa bank adalah suatu badan usaha yang menghimpun dana masyarakat dalam bentuk simpanan dan menyalurkan kepada masyarakat dalam bentuk kredit dan atau bentuk-bentuk lainnya dalam rangka meningkatkan taraf hidup rakyat banyak. Bank dapat dibedakan menjadi dua macam. Yaitu bank konvensional dan bank syariah.

Perbedaan utama antara bank syariah bank konvensional adalah prinsip hukum yang digunakan. Pada bank syariah menerapkan prinsip syariah dalam melaksanakan kegiatan 
usahanya. Bank syariah terdiri dari Bank Umum Syariah (BUS), Bank Pembiayaan Rakyat Syariah (BPRS), dan Unit usaha Syariah(UUS). Sedangkan pada bank konvensional menerapkan prinsip secara konvensional dalam melaksanakan kegiatan usahanya. Bank konvensional terdiri dari Bank Umum Konvensional (BUK) dan Bank Perkreditan Rakyat (BPR).

Lembaga keuangan syariah seperti Bank Umum Syariah (BUS), Bank Pembiayaan Rakyat Syariah (BPRS), Unit Usaha Syariah (UUS), maupun Baitul Maal wat Tamwil (BMT) menerapkan konsep syariah dan sistem operasional yang sama. Akan tetapi yang membedakan Bank Umum Syariah (BUS), Bank Pembiayaan Rakyat Syariah (BPRS), dan Baitul Maal wat Tamwil (BMT) adalah skala bisnisnya. BMT dalam menghimpun dana dan menyalurkan dana dalam jumlah yang kecil dan mikro karena resiko yang ditanggung oleh BMT lebih kecil daripada Bank Umum Syariah (BUS) dan Bank Pembiayaan Rakyat Syariah (BPRS). Selain itu, sdanya BMT dianggap masih relatif baru dalam kegiatan perekonomian maupun perbankan. Hal ini yang menyebabkan jumlah dana yang dihimpun dan disalurkan oleh BMT kepada anggotanya kecil dan mikro. ${ }^{1}$

Dalam perkembangannya BMT AL-HIKMAH mendapatkan kepercayaan yang tinggi dari anggotanya. Ditandai dengan sejak awal berdirinya pada tanggal 24 September 1998 hingga sekarang, total anggota nya mencapai lebih dari 12.000 orang yang tersebar di delapan cabang di wilayah Kabupaten Ungaran. Antara lain Mijen Gedanganak, Gunungpati, Sekaran, Babadan, Karangjati, Bawen, Bandungan dan LKK. Tingkat kepercayaan masyarakat Kabupaten Ungaran terhadap BMT AL-HIKMAH dapat dipengaruhi oleh beberapa faktor. Termasuk faktor dari prinsip syariah yang digunakan oleh BMT AL-HIKMAH.

BMT menerapkan prinsip wadiah dan mudharabah pada produk penghimpunan dana serta prinsip murabahah, ijarah, pada produk penyaluran dana. Oleh karena itu, penulis ingin meneliti penerapan prinsip wadiah, mudharabah dan murabahah pada lembaga keuangan syariah dalam hal ini adalah BMT AL-HIKMAH.

\section{Rumusan Masalah}

Berdasarkan uraian latar belakang dari penelitian ini, maka dapat dirumuskan dua masalah sebagai berikut: pertama, Bagaimana penerapan prinsip wadi'ah, mudharabah, dan murabahah pada BMT AL-HIKMAH?. Kedua Apakah penerapan prinsip wadi'ah, mudharabah, dan murabahah pada BMT AL-HIKMAH dilakukan sesuai dengan prinsip syariah yang berlaku?. Ketiga, Bagaimana penerapan prinsip wadi'ah, mudharabah, dan murabahah pada BMT ALHIKMAH yang sesuai dengan prinsip syariah yang berlaku?

\section{Metode Penelitian}

Dalam mengkaji penelitian ini, metode penelitian yang paling tepat digunakan adalah metode penelitian kualitatif. Metode penelitian kualitatif merupakan metode penelitian yang dilakukan dengan menyimpulkan berdasarkan hasil pengamatan dan pendapat dari pihak BMT AL-HIKMAH dan anggota BMT AL-HIKMAH.

Objek penelitian ini adalah informasi yang berasal dari pihak BMT AL-HIKMAH, pihak anggota di BMT AL-HIKMAH, dokumen yang berhubungan dengan penerapan prinsip wadi' ah, mudharabah, dan murabahah pada BMT AL-HIKMAH.

Metode pengumpulan data yang digunakan dalam penelitian ini ada tiga. Yaitu melalui metode observasi, wawancara, dan dokumen. Metode pengumpulan data yang pertama yaitu dengan observasi yaitu dilakukan dengan pengamatan yang melibatkan semua indera (penglihatan, pendengaran, penciuman, pembau, perasa). Pencatatan hasil dapat dilakukan dengan bantuan alat rekam elektronik. Metode pengumpulan data yang kedua yaitu wawancara. Wawancara dilakukan dengan cara pengambilan data melalui wawancara /secara lisan langsung dengan sumber datanya, baik melalui tatap muka atau lewat telephone, teleconference.

1 Muthaher, Osmad, 2012, Akuntansi Perbankan Syariah, Yogyakarta : Graha Ilmu, Edisi Pertama. 
Jawaban responden direkam dan dirangkum sendiri oleh peneliti. Metode pengumpulan data yang kedua yaitu dokumen. Dokumen diperoleh dengan cara meminta data melalui dokumen tertulis mamupun elektronik dari lembaga/institusi. Dokumen diperlukan untuk mendukung kelengkapan data yang lain.

\section{Hasil Dan Pembahasan}

Penulis melakukan wawancara dengan pihak BMT AL-HIKMAH dengan narasumber langsung dari pihak BMT AL-HIKMAH yaitu Ibu Asroti, S. Pd. I. selaku Pengurus BMT ALHIKMAH yang menjabat sebagai Bendahara dan Bapak MD Burhannudin M,S.Pd selaku Manajer kantor BMT AL-HIKMAH cabang Mijen Gedanganak. Wawancara ini dilakukan dengan tujuan memperkuat data mengenai penerapan prinsip wadi'ah, mudharabah, dan murabahah yang diterapkan oleh BMT AL-HIKMAH. Selain wawancara, penulis juga melakukan pengamatan terhadap penerapan prinsip wadi'ah, mudharabah, dan murabahah yang berlaku di BMT AL-HIKMAH pada saat melaksanakan magang di BMT AL-HIKMAH selama tiga minggu terhitung mulai tanggal 15 Agustus 2016 sampai dengan 3 September 2016.

Berdasarkan hasil wawancara kepada pihak BMT AL-HIKMAH, penulis dapat menyimpulkan bahwa BMT AL-HIKMAH tumbuh dan berkembang di wilayah Kecamatan Ungaran. Lahirnya Koperasi BMT ini diawali dengan adanya pertemuan 30 tokoh masyarakat Babadan dan sekitarnya pada tanggal 24 September 1998 di masjid Wahyu Langensari. Pertemuan tersebut membahas tentang pendirian BMT AL-HIKMAH. Tokoh-tokoh masyarakat yang hadir telah sepakat untuk siap menjadi anggota pendiri. BMT AL-HIKMAH bertujuan untuk menciptakan sebuah lembaga perekonomian masyarakat sebagai sarana untuk meningkatkan kualitas kehidupan sosial ekonomi umat islam. Sasaran utamanya adalah para pengusaha kecil, pedagang dan masyarakat umum menengah kebawah di wilayah Kecamatan Ungaran. Salah satu unit usahanya ialah unit simpan pinjam dengan menggunakan sistem bagi hasil. Adapun target yang hendak dicapai ialah terbentuknya pusat perekonomian umat melalui kegiatan usaha mencapai kesejahteraan hidup umat.

BMT AL- HIKMAH mulai beroperasi di komplek Pasar Babadan Blok-26, pada tanggal 15 Oktober 1998 dengan modal awal sebesar Rp. 15.000.000.00 (Lima Belas Juta Rupiah). Modal awal tersebut berasal dari simpanan yang disetorkan para anggota BMT AL-HIKMAH berupa simpanan pokok, simpanan pokok khusus, dan simpanan wajib. BMT AL-HIKMAH mengalami perkembangan yang cukup pesat. Selama sepuluh tahun berdiri, jumlah anggotanya meningkat, sejalan dengan meningkatnya jumlah nominal simpanan yang harus disetorkan. Sampai bulan Februari 2012 tercatat 4.859 anggota dengan nominal simpanan lebih dari 6 milyar. Untuk kredit yang disalurkan juga mengalami peningkatan, seiring dengan peningkatan dan tentunya meningkat pula rugi laba setiap bulannya.

Saat ini koperasi BMT AL- HIKMAH menempati kantor pusat sekaligus kantor cabang di J1. Jend. Sudirman No. 12 Mijen Gedanganak Ungaran Timur Kab. Semarang. Selain kantor cabang di Mijen Gedanganak, juga terdapat tujuh kantor cabang lain. Yaitu di komplek pasar Babadan Blok E 23-25, di komplek terminal pasar Karangjati No. 11 Kecamatan Bergas, di komplek Bandungan No. 07, Kecamatan Bandungan, di komplek Bawen, dan di Jalan Taman Siswa No. 13 Sekaran Gunung Pati, di pertigaan pasar Gunungpati dan di LKK.

BMT AL-HIKMAH memiliki visi dan misi yang luar biasa. Misinya yaitu menjadi lembaga keuangan syari'ah yang sehat, professional, dan terpercaya di Jawa Tengah. Selain itu, visinya adalah meminimalkan Non Profit Loan (NPF), memperbaiki struktur permodalan, meningkatkan penghimpunan dana anggota dan calon anggota, meningkatkan pendapatan koperasi, meningkatkan SDM yang handal dan kompeten, meningkatkan kepercayaan masyarakat terhadap koperasi BMT, dan meningkatkan pengelolaan koperasi secara professional.

Stuktur Organisasi BMT AL-HIKMAH yang hampir sama dengan BMT pada umunya. Susunan Manajemen BMT AL- HIKMAH Ungaran tahun 2016 terdiri dari pengawas, pengurus, 
dan pengelola. Pengawas di ketuai oleh Gatot Indramotko,S.E., membawahi dua anggota yaitu anggota 1 Drs. Toni Irianto dan anggota 2 Drs. H. Abu Hanafi. Pengurus diketuai oleh Muhari S.Ag, dengan sekretaris Ichsan Ma'arif, ST dan bendahara Asroti, S. Pd. I. Untuk pengelola, terdiri dari : pertama, Kantor Pusat dan Cabang Mijen Gedanganak : MD Burhannudin M,S. Pd., Mudhofar, Ahwat Adi Wibowo, Heni Fajar R, S. Pd, Sayfur Rochman, Saefudin, Dani Mahardika Safik, Badi Aliana, dan Nurkhasan. Kedua, Kantor Cabang Babadan : Awing Fraptiyo, S.E., Abdurrohim, Isna Ira Setyawati, S.E., Nurul Huda Amrullah, Abdul Chamid, Salamti Nurul A, dan Fahrul Saktiana. Ketiga Kantor Cabang Karangjati : Yuni Fatmawati, S.E., Mujana, Deny Purniawan, Dian Irvani, A.Md. Keempat, Kantor Cabang Bawen : Supandriyo, A.Md., Sefi Aprillia, A.Md., Imam Santosa, S.E. Kelima, Kantor Cabang Bandungan : Nur Jannah, Sulamin, Masyudi, A. Md., Hadi Muta'ali. Keenam, Kantor cabang Gunung Pati I : Ahmad Syariffudin, Nida'ulwiyah, dan S.HI. Zulikhan Yahya. Serta yang ketujuh Kantor cabang Gunung Pati II : Eko Susilo, S.E., Yathi'udin H, S. Si, dan Kharis Muhandis, A.Md. ${ }^{2}$

Produk-produk BMT AL- HIKMAH terbagi atas produk penghimpunan dana dan produk penyaluran dana kepada para anggota. Produk penghimpunan dana dirancang khusus atas dasar syari' ah, terdiri dari beberapa jenis simpanan, antara lain: Simpanan Sukarela Lancar (SIRELA), Simpanan Pelajar (SIMPEL), Simpanan Sukarela Qurban (SISUQUR), Simpanan Ibadah Haji (SIHAJI), Simpanan Ibadah Umroh (SIUMROH), dan Simpanan Sukarela Berjangka (SISUKA). Sedangkan produk penyaluran dana berupa jenis pembiayaan berupa modal usaha, dan sewa barang atau jasa. Beberapa jenis pembiayaan yang disediakan sebagai berikut : Prinsip Jual Beli Murabahah, Prinsip Jasa Ijaroh, dan Prinsip Mudharabah/Musyarakah. ${ }^{3}$

Simpanan Sukarela Lancar merupakan simpanan anggota masyarakat yang didasarkan akad wadi'ah yad dhamanah. Simpanan Pelajar merupakan simpanan yang ditujukan kepada para pelajar dan mahasiswa yang menginginkan memiliki rekening simpanan yang akan terus bertumbuh dan berkesempatan untuk mengajukan beasiswa bagi pelajar yang berprestasi. Simpanan Sukarela Qurban adalah simpanan anggota yang dirancang khusus sebagai sarana mempersiapkan dana untuk melaksanakan ibadah penyembelihan hewan qurban. Penyetoran dapat dilakukan sewaktu-waktu sedangkan penarikan atau pencairannya hanya dapat dilakukan pada bulan Dzulhijjah saat pelaksanaan penyembelihan hewan qurban. Simpanan Ibadah Haji merupakan inovasi baru dari BMT AL- HIKMAH yang dikhususkan bagi Anda Masyarakat Muslim yang berencana menunaikan Ibadah Haji. Simpanan Terencana Ibadah Umroh merupakan inovasi baru dari BMT AL-HIKMAH sebagai sarana mempersiapkan dana secara berkalasesuai jangka waktu yang diinginkan dalam melaksanakan Ibadah Umroh. Simpanan Sukarela Berjangka merupakan simpanan berjangka dengan prinsip syari'ah yang memberikan hasil investasi yang optimal bagi anggota BMT AL- HIKMAH.

Akad Murabahah adalah akad jual beli atas barang tertentu, dimana penjual menyebutkan dengan jelas barang yang diperjualbelikan, termasuk harga pembelian barang kepada pembeli, kemudian ia mensyaratkan atasnya laba/keuntungan dalam jumlah tertentu. Fasilitas pembiayaan diperuntukkan bagi Anggota yang menginginkan memiliki barang atau peralatan usaha guna mendukung kegiatan usaha anggota. Ijaroh disebut akad pemindahan hak guna (manfaat) atas suatu barang atau jasa dalam waktu tertentu melalui pembayaran sewa/upah, tanpa diikuti dengan pemindahan kepemilikan itu sendiri. Fasilitas pembiayaan diperuntukkan bagi Anggota yang terkendala dalam membayar biaya pendidikan, biaya sewa rumah, biaya sewa tempat usaha, biaya perawatan rumah sakit, biaya perjalanan dan biaya lain yang diperlukan. Mudharabah/ musyarakah merupakan fasilitas pembiayaan diperuntukkan bagi anggota yang menginginkan permodalan dalam pengembangan usaha yang digelutinya, agar usahanya tersebut menjadi lebih besar dan menguntungkan.

2 Irena Widyastuti, Nur Hamidah, 2016, Sistem Operasional dan Pemasaran BMT AL-HIKMAH, Semarang : Fakultas Ekonomi UNISSULA, Laporan Magang.

3 Irena Widyastuti, Nur Hamidah, 2016, Sistem Operasional dan Pemasaran BMT AL-HIKMAH, Semarang : Fakultas Ekonomi UNISSULA, Laporan Magang. 
Berdasarkan prinsip-prinsip yang diterapkan oleh BMT AL-HIKMAH. Maka penulis membandingkan dengan prinsip dalam hukum islam. Didalam prinsip operasional bank syariah ada beberapa prinsip. Antara lain prinsip wadi' ah, mudharabah, musyarakah, murabahah, ijaroh,

Prinsip Titipan (Wadi'ah) dalam segi bahasa dapat diartikan sebagai meninggalkan atau meletakkan sesuatu kepada orang lain untuk dipelihara dan dijaga. Dari aspek teknis wadia'ah dapat diartikan sebagai titipan murni dari satu pihak ke pihak lainnya, baik individu maupun badan hukum, yang harus dijaga dan dikembalikan kapan saja si penitip kehendaki. Landasan Hukumnya adalah QS. An-nisaa (4) : 58. Artinya : "Sesungguhnya Allah menyuruh kamu menyampaikan amanat kepada yang berhak menerimanya, dan (menyuruh kamu) apabila menetapkan hukum di antara manusia supaya kamu menetapkan dengan adil. Sesungguhnya Allah memberi pengajaran yang sebaik-baiknya kepadamu. Sesungguhnya Allah adalah Maha mendengar lagi Maha melihat". 4

Simpanan/tabungan yang berakad wadiah ada dua, yaitu wadiah yad-amanah dan wadiah yad-dhamanah. Wadiah Yad-Amanah yaitu akad yang menyatakan bahwa penerima titipan tidak boleh memanfaatkan barang yang dititipkan. Tetapi harus tetap menjaganya sesuai kelaziman. Pihak penerima titipan dapat membebankan biaya kepada penitip sebagai penitipan. Wadi'ah Amanah yang dimaksud disini biasanya berupa dana ZIS (Zakat,infak dan shadaqoh) yang dimiliki oleh 8 asnaf mustahik dan disalurkan baik dalam bentuk mustahik produktif maupun konsumtif. Wadi'ah Yad-Dhamanah dapat diartikan sebagai titipan murni dimana dana yang dititipkan boleh digunakan (diambil manfaatnya) oleh penitip. Penyimpan mempunyai kewajiban untuk bertanggung jawab terhadap kehilangan dana tersebut. Semua keuntungan yang diperoleh dari titipan tersebut menjadi hak penerima titipan. Sebagai imbalan kepada pemilik dana dapat diberikan semacam insentif berupa bonus yang tidak disyaratkan sebelumnya. ${ }^{5}$

"Diriwayatkan dari Abu Rafie bahwa Rasulullah pernah meminta seseorang untuk meminjamkannya seekor unta. Maka diberikannya unta qurban. Setelah selang beberapa waktu Abu Rafie diperintahkan Rasulullah untuk mengembalikan unta tersebut kepada pemiliknya, tetapi Abu Rafie kembali berbalik menghadap Rasulullah seraya berkata "Ya Rasulullah untuk yang sepadan tidak kami temukan, hanya untuk yang lebih besar dan berumur empat tahun" Rasulullah SAW membalas sambil berkata "Berikan itu karena sesungguhnya sebaik-baik kamu adalah yang terbaik ketika membayar"

Dalam hal ini Produk penghimpunan dana lembaga keuangan syariah (Himpunan Fatwa DSN-MUI, 2003) yang menjadi bagian dari simpanan wadi'ah yaitu: giro wadiah. Giro wadiah adalah produk simpanan yang bisa ditarik kapan saja. Dana nasabah dititipkan di LKMS dan boleh dikelola. Setiap saat nasabah berhak mengambilnya dan berhak mendapatkan bonus dari keuntungan pemanfaatan dana giro oleh LKMS. Besarnya bonus tidak ditetapkan di muka tetapi benar-benar merupakan kebijaksanaan LKMS. Sungguhpun demikian nominalnya diupayakan sedemikian rupa untuk senantiasa kompetitif (Fatwa DSN-MUI No. 01/DSN-MUI/IV/2000).

Prinsip Mudharabah adalah salah satu akad kerjasama kemitraan berdasarkan prinsip berbagi untung dan rugi, dilakukan sekurang-kurangnya oleh dua pihak, dimana pihak pertama memiliki dan menyediakan modal, disebut shahibul mal, sedang yang kedua memiliki keahlian (skill) dan bertanggung jawab atas pengelolaan dana/manajemen usaha (proyek) tertentu, disebut mudharib. Dalam kerangka penghimpunan dana mudharabah, nasabah bertindak sebagai shahibulmal dan BMT sebagai mudharib. BMT dapat menawarkan produk penghimpunan dana mudharabah ini kepada masyarakat dengan menunjukkan cara-cara penentuan dan perhitunganporsi bagi hasilnya, dan perlu dicatat, BMT tidak diperkenankan menjanjikan pemberian keuntungan tetap perbulan dalam jumlah tertentu dengan sistem persentase sebagaimana lazim berlaku dalam tatanan perbankan konvensional, atau dalam jumlah tertentu atas dasar kalkulasi angka-angka rupiah.

$4 \quad$ Sudarsono,Heri.Bank dan Lembaga Keuangan Syari'ah Deskripsi dan Ilustrasi, Yogyakarta: Ekonisia.2003. hal 57.

5 Wiroso,Penghimpunan Dana dan Distribusi Hasil Usaha Bank Syariah(Jakarta: PT. Gramedia WidiasaranaIndonesia, 2005), hlm.22-23 
Dalam Penghimpunan Dana beprinsip Mudharabah ini akad yang digunakan, yaitu Mudharabah Mutlaqah (Investasi Tidak Terikat) yang tujuan utama shahibul mal menempatkan dana di Lembaga Keuangan adalah untuk mendapatkan hasil/keuntungan (Profit Oriented), artinya nasabah menempatkan dana di BMTdengan konsep investasi. Konsekuensinya, nasabah harus bisa mengikuti aturan atau ketentuanatau batasan yang sudah ditetapkan oleh BMT sebagai pengelola dana (Mudharib) agar dana mereka bisa menghasilkan atau produktif. Sesuai dengan ketetentuan Himpunan Fatwa DSN-MUI, 2003 mengenai produk perhimpunan dana Lembaga Keuangan Syari'ah, dimana mudharabah Mutlaqah menggunakan dua aplikasi LKMS yaitu: Tabungan Mudharabah yaitu dana yang disimpan nasabah akan dikelola LKMS, untuk memperoleh keuntungan. Keuntungan akan diberikan kepada nasabah berdasarkan kesepakatan nasabah. Nasabah bertindak sebagai shahibul mal dan lembaga keuangan syariah bertindak sebagai mudharib (Fatwa DSN-MUI No. 02/DSN-MUI/IV/2000). Deposito Mudharabah yaitu LKMS bebas melakukan berbagai usaha yang tidak bertentangan dengan syariah dan mengembangkannya. LKMS bebas mengeola dana (Mudharabah Mutaqah). LKMS berfungsi sebagai mudharib sedangkan nasabah juga shahibul maal. Ada juga dana nasabah yang dititipkan untuk usaha tertentu. Nasabah memberi batasan penggunn dana untuk jenis dan tempat tertentu. Jenis ini disebut Mudharabah Muqayyadah. Selain itu ada Mudharabah Muqayyadah (Investasi terikat) dimana nasabah mempercayai BMT sebagai Lembaga Keuangan yang kompeten, bisa dipercaya serta bisa memproduktifkan dana mereka, tanpa harus mengetahui secara detail pengelolaan/penggunaan dananya atau dengan kata lain memberikan keleluasaan dan kebebasan kepada mudharib dalampengelolaan investasinya. Dana Investasi Tidak Terikat ini diaplikasikan dalam bentuk produk Simpanan/Tabungan dan Deposito (Simpanan Berjangka). ${ }^{6}$

Disamping produk penghimpunan dan, ada pula produk Penyaluran Dana (Lending). Produk penyaluran dana yang disediakan oleh BMT bisa mendasarkan pada akad-akad tradisional Islam, yakni akad jual beli, akad sewa menyewa, akad bagi hasil dan akad pinjam meminjam.Dalam kegiatan penyaluran dananya, secara garis besar pembiayaan BMT dapat dibedakan menurut tujuan penggunaannya, yaitu: jual beli; terdiri dari murabahah,

Jual beli adalah akad antara penjual dan pembeli untuk melakukan transaksi jual beli dimana objeknya adalah barang dan harga. Penerapan akad jual beli ini dalam transaksi BMT tampak dalam produk pembiayaan murabahah, salam, dan istishna. Adapun pengertian dari jenis -jenis pembiayaan tersebut adalah sebagai berikut: Murabahah, yaitu jual beli barang sebesar harga pokok barang ditambah margin keuntungan yang telah disepakati. Salam, yaitu jual beli barang dengan pemesanan dengan syaratsyarat tertentu dan pembayaran tunai terlebih dahulu secara penuh. Istishna, yaitu jual beli barang dalam bentuk pemesanan pembuatan barang dengan kriteria dan persyaratan tertentu yang telah disepakati dengan pembayaran sesuai dengan kesepakatan.

Setelah dilakukan perbandingan antara penerapan prinsip wadi'ah, mudharabah, dan murabahah pada BMT AL-HIKMAH terhadap prinsip wadi'ah, mudharabah, dan murabahah yang sesuai dengan prinsip syariah. Hasil menunjukkan bahwa BMT AL-HIKMAH menerapkan akad wadi' ah yad dhamanah pada Simpanan Sukarela Lancar (SIRELA). Prinsip akad wadia'ah yad dhamanah adalah dapat diartikan sebagai titipan murni dimana dana yang dititipkan boleh digunakan (diambil manfaatnya) oleh penitip. Penyimpan mempunyai kewajiban untuk bertanggung jawab terhadap kehilangan dana tersebut. Semua keuntungan yang diperoleh dari titipan tersebut menjadi hak penerima titipan. Sebagai imbalan kepada pemilik dana dapat diberikan semacam insentif berupa bonus yang tidak disyaratkan sebelumnya. Dalam pelaksanaannya, BMT AL-HIKMAH memberikan imbalan kepada pemilik dana melalui semacam insentif berupa bonus yang tidak disyaratkan sebelumnya dan diberikan setiap bulan. Insentif berupa bonus yang diberikan kepada pemilik dana diberikan sesuai marginnya yang sudah ditetapkan oleh pihak BMT sesuai dengan saldo dana yang dimiliki oleh pemilik dana

6 Sudarsono, Heri, 2003, Bank dan Lembaga Keuangan Syari'ah Deskripsi dan Ilustrasi, Yogyakarta: Ekonisia, hal 57. 
dan tidak disyaratkan pada awal anggota mulai menanamkan dananya ke BMT. Jadi, BMT AL-HIKMAH telah menerapkan prinsip wadi'ah sesuai dengan prinsip hukum syariah yang berlaku. Prinsip wadi'ah ini selain diterapkan pada produk penghimpunan dana lainnya yang ada di BMT AL-HIKMAH. Yaitu produk Simpanan Sukarela Lancar (SIRELA), akan tetapi juga diterapkan pada Simpanan Pelajar (SIMPEL), Simpanan Sukarela Qurban (SISUQUR), Simpanan Ibadah Haji (SIHAJI), dan Simpanan Ibadah Umroh (SIUMROH).

Pada Simpanan Sukarela Lancar (SIRELA) bisa juga disebut dengan prinsip mudharabah diterapkan oleh BMT AL-HIKMAH. Karena pada Simpanan Sukarela Lancar (SIRELA) ini insentif berupa bonus yang diberikan kepada pemilik dana diberikan secara terus menerus. Dan besarnya insentif yang diberikan adalah berdasarkan jumlah dana yang dimiliki oleh pemilik dana. Semakin besar dana yang dimiliki anggota, maka semakin besar pula jumlah insentif yang diberikan kepada pemilik dana. Begitu pula sebaliknya, semakin besar dana yang dimiliki anggota, maka semakin besar pula jumlah insentif yang diberikan kepada pemilik dana. Hal ini mirip dengan prinsip mudharabah. Prinsip Mudharabah adalah salah satu akad kerjasama kemitraan berdasarkan prinsip berbagi untung dan rugi, dilakukan sekurang-kurangnya oleh dua pihak, dimana pihak pertama memiliki dan menyediakan modal, disebut shahibul mal, sedang yang kedua memiliki keahlian (skill) dan bertanggung jawab atas pengelolaan dana/ manajemen usaha (proyek) tertentu, disebut mudharib. Dalam kerangka penghimpunan dana mudharabah, nasabah bertindak sebagai shahibulmal dan BMT sebagai mudharib. BMT dapat menawarkan produk penghimpunan dana mudharabah ini kepada masyarakat dengan menunjukkan cara-cara penentuan dan perhitunganporsi bagi hasilnya, dan perlu dicatat, BMT tidak diperkenankan menjanjikan pemberian keuntungan tetap perbulan dalam jumlah tertentu dengan sistem persentase sebagaimana lazim berlaku dalam tatanan perbankan konvensional, atau dalam jumlah tertentu atas dasar kalkulasi angka-angka rupiah.

Dari berbagai pertimbangan, maka pada Simpanan Sukarela Lancar (SIRELA) lebih tepat disebut menggunakan prinsip wadi' ah yad-dhamanah. Karena meskipun pada Simpanan Sukarela Lancar (SIRELA) ini insentif berupa bonus yang diberikan kepada pemilik dana diberikan secara terus menerus. Dan besarnya insentif yang diberikan adalah berdasarkan jumlah dana yang dimiliki oleh pemilik dana. Semakin besar dana yang dimiliki anggota, maka semakin besar pula jumlah insentif yang diberikan kepada pemilik dana. Begitu pula sebaliknya, semakin besar dana yang dimiliki anggota, maka semakin besar pula jumlah insentif yang diberikan kepada pemilik dana.

Wadi' ah yad-dhamanah adalah titipan murni dimana dana yang dititipkan boleh digunakan (diambil manfaatnya) oleh penitip. Penyimpan mempunyai kewajiban untuk bertanggung jawab terhadap kehilangan dana tersebut. Semua keuntungan yang diperoleh dari titipan tersebut menjadi hak penerima titipan. Sebagai imbalan kepada pemilik dana dapat diberikan semacam insentif berupa bonus yang tidak disyaratkan sebelumnya. Insentif berupa bonus yang tidak disyaratkan sebelumnya ini merupakan cirri khas dari prinsip wadi'ah. Jadi bonus diberikan sesuai dengan keinginan pihak BMT akan memberikan berapa jumlahnya bonus tersebut walaupun pihak anggota atau pemilik dana tidak berharap diberikan bonus. Jadi, penggunaan prinsip wadi'ah di BMT AL-HIKMAH sudah sesuai dengan prinsip hukum syariah.

Hasil kedua mengenai prinsip mudharabah menunjukkan bahwa BMT AL-HIKMAH menerapkan akad mudharabah pada produk Simpanan Sukarela Berjangka merupakan simpanan berjangka dengan prinsip syari'ah yang memberikan hasil investasi yang optimal bagi anggota BMT AL- HIKMAH. Karena margin diberikan pada saat nisbah yang ditentukan diawal dengan perbandingan yang sudah ditentukan pada saat awal perjanjian saat pamilik dana menanamkan dananya kepada pihak BMT untuk dilakukan perputaran dana yang akhirnya akan menghasilkan bagi hasil sesuai dengan dana yang dimiliki. Akad Mudharabah Muqayyadah (Investasi terikat) dimana nasabah mempercayai BMT sebagai Lembaga Keuangan yang kompeten, bisa dipercaya serta bisa memproduktifkan dana mereka, tanpa harus mengetahui 
secara detail pengelolaan/penggunaan dananya atau dengan kata lain memberikan keleluasaan dan kebebasan kepada mudharib dalampengelolaan investasinya. Dana Investasi Tidak Terikat ini diaplikasikan dalam bentuk produk Simpanan/Tabungan dan Deposito (Simpanan Berjangka). Di dalam pelaksanaannya BMT AL-HIKMAH sudah melaksanakan prinsip mudharabah muqayyadah dalam produk Simpanan Sukarela Berjangka (SISUKA). Dengan berbagai perjanjian yang sesuai dengan prinsip hukum islam. Pada produk Simpanan Sukarela Berjangka (SISUKA) margin ditentukan sesuai dengan jumlah dana dan jangka waktu yang di inginkan oleh pemilik dana dalam menginvestasikan dananya kepada BMT AL-HIKMAH. Meskipun pihak BMT sudah menetapkan margin sesuai dengan jumlah dana dan jangka waktu yang ditentukan, akan tetapi nisbah bagi hasil tetap masih ditetapkan bersama atas keputusan bersama di awal perjanjian agar tidak menimbulkan masalah untuk masa yang akan datang. Prinsip mudharabah ini juga memiliki ketentuan apabila dana dari pemilik dana diambil sebelum jatuh tempo Simpanan Sukarela Berjangka (SISUKA) tersebut maka bagi hasil yang dihasilkan dan semestinya diberikan kepada pemilik dana pada saat waktu jatuh tempo dibatalkan untuk diberikan karena sudah disepakati diawal bahwa bagi hasil akan diberikan pada saat jatuh tempo. Jadi, dalam hal ini, BMT AL-HIKMAH sudah menerapkan prinsip mudharabah sesuai dengan prinsip hukum islam pada produk Simpanan Sukarela Berjangka (SISUKA).

Hasil ketiga mengenai prinsip murabahah menunjukkan bahwa BMT AL-HIKMAH menerapkan akad murabahah pada produk penyaluran dana atau pembiayaan pada prinsip jual beli barang. Berikut ini tata cara adalah bagan alir Sistem Operasional Perusahaan untuk Pengajuan dan persetujuan pembiayaan murabahah sekaligus proses pencairan pembiayaan dan pengambilan barang dilakukan sebanyak dua belas proses. Yaitu Pertama, nasabah mempersiapkan berbagai dokumen antara lain permohonan PYD, data perusahaan, spesifikasi barang, dan dokumen lain yang diperlukan. Selanjutnya diserahkan kepada account officer. Kedua, supplier mempersiapkan dokumen data supplier dan konfirmasi tersedianya barang. Selanjutnya diserahkan kepada account officer. Ketiga, account officer melakukan analisa dokumen dari nasabah dan supplier. Keempat, setelah melakukan analisa, account officer menyerahkan hasil analisa kepada komite pembiayaan. Dan unit support juga memberikan analisa yuridis nasabah dan supplier sebagai vahan pertimbangan komite pembiayaan untuk memberikan keputusan. Kelima, komite pembiayaan memberikan keputusan apakah pengajuan pembiayaan murabahah tersebut ditolak atau disetujui. Keenam, jika ditolak, nasabah akan menerima dokumen surat penolakan kepada nasabah dan berkas dapat diambil kembali. Jika disetujui, komite pembiayaan menentukan harga beli, harga jual, jangka waktu, supplier, dan barang. Ketujuh, account officer membuat surat persetujuan pembiayaan dan supplier membuat surat pernyataan sanggup. Kedelapan, selanjutnya surat persetujuan pembiayaan akan diberikan kepada nasabah hingga akhirnya setuju membayar uang muka. Kesembilan, uang muka dari nasabah diserahkan kepada unit support untuk dibuatkan tanda terima uang muka murabahah, surat pemesanan barang kepada supplier, akad murabahah BMT dan supplier, dan akad murabahah BMT dan nasabah. Kesepuluh, surat pemesanan barang kepada supplier dikirim ke supplier hingga supplier menyatakan bahwa barang tersedia dan siap dikirim sekaligus membuat surat permohonan realisasi murabahah kepada unit support. Kesebelas, unit support melakukan instruksi pembayaran kepada supplier. Keduabelas, supplier membuat dokumen tanda terima uang dan membuat invoice yang dilanjutkan surat pengiriman barang pada nasabah. Terakhir nasabah menandatangani tanda terima barang oleh nasabah. Dan menghubungi unit support untuk melunasi harga jual secara sekaligus atau mengangsur. Prinsip Murabahah yaitu jual beli barang sebesar harga pokok barang ditambah margin keuntungan yang telah disepakati. pihak BMT tidak menentukan margin keuntungan diawal. Akan tetapi, besarnya margin keuntungan ditentukan bersama anggota yang mengajukan pembiayaan berprinsip akad murabahah jual beli barang. Karena BMT juga melakukan kerjasama dengan dealer sepeda motor. Jadi, di 
dalam melaksanakan prinsip murabahah pada produk pembiayaan jual beli perusahaan sudah dilakukan sesuai dengan prinsip hukum syariah.

\section{Penutup}

Berdasarkan hasil analisis, dapat disimpulkan bahwa prinsip wadi'ah, prinsip mudharabah, dan prinsip murabahah pada BMT AL-HIKMAH sudah dilaksanakan sesuai dengan prinsip hukum syariah. pada Simpanan Sukarela Lancar (SIRELA) lebih tepat disebut menggunakan prinsip wadi'ah yad-dhamanah. Karena meskipun pada Simpanan Sukarela Lancar (SIRELA) ini insentif berupa bonus yang diberikan kepada pemilik dana diberikan secara terus menerus. Semua keuntungan yang diperoleh dari titipan tersebut menjadi hak penerima titipan. Sebagai imbalan kepada pemilik dana dapat diberikan semacam insentif berupa bonus yang tidak disyaratkan sebelumnya. Insentif berupa bonus yang tidak disyaratkan sebelumnya ini merupakan cirri khas dari prinsip wadi'ah. Jadi bonus diberikan sesuai dengan keinginan pihak BMT akan memberikan berapa jumlahnya bonus tersebut walaupun pihak anggota atau pemilik dana tidak berharap diberikan bonus.

Prinsip mudharabah diterapkan pada produk Simpanan Sukarela Berjangka (SISUKA) margin ditentukan sesuai dengan jumlah dana dan jangka waktu yang di inginkan oleh pemilik dana dalam menginvestasikan dananya kepada BMT AL-HIKMAH. Meskipun pihak BMT sudah menetapkan margin sesuai dengan jumlah dana dan jangka waktu yang ditentukan, akan tetapi nisbah bagi hasil tetap masih ditetapkan bersama atas keputusan bersama di awal perjanjian agar tidak menimbulkan masalah untuk masa yang akan datang.

Murabahah yaitu jual beli barang sebesar harga pokok barang ditambah margin keuntungan yang telah disepakati. pihak BMT tidak menentukan margin keuntungan diawal. Akan tetapi, besarnya margin keuntungan ditentukan bersama anggota yang mengajukan pembiayaan berprinsip akad murabahah jual beli barang. Dan realisasi pembiayaan murabahah bukanlah dalam bentuk uang, melainkan benar-benar berupa barang. Jadi, BMT AL-HIIKMAH sudah menerapkan prinsip syariah sebagai lembaga keuangan syariah.

\section{Daftar Pustaka}

Handoko T. Hani, 1995, Manajemen, Yogyakarta : BPFE, Edisi Dua

Irena Widyastuti, Nur Hamidah, 2016, Sistem Operasional dan Pemasaran BMT AL-HIKMAH, Semarang : Fakultas Ekonomi UNISSULA, Laporan Magang

Muhammad, 2002, Manajemen Bank Syariah, Yogyakarta : AMP YKPN

Muthaher, Osmad, 2012, Akuntansi Perbankan Syariah, Yogyakarta : Graha Ilmu, Edisi Pertama

Sudarsono, Heri, 2003, Bank dan Lembaga Keuangan Syari'ah Deskripsi dan Ilustrasi, Yogyakarta: Ekonisia

Triandini, Hendri, 2013, Pengaruh Layanan Jemput Bola Produk Funding Terhadap DPK dan Jumlah Nasabah: Studi Pada BPRS Artha Karimah Irsyadi, Jurnal Etikonomi Vol. 12 No. 2, Oktober 2013

Ulfa, Lailatul, 2011, Pengaruh Strategi Pemasaran Jemput Bola Terhadap Peningkatan Jumlah Nasabah di UJKS BMT Mitra Umat Pekalongan, Pekalongan: STAIN Pekalongan

Wiroso,2005, Penghimpunan Dana dan Distribusi Hasil Usaha Bank Syariah, Jakarta: PT. Gramedia WidiasaranaIndonesia 